\title{
A semi-selective medium to isolate and identify bacteria of the genus Pantoea
}

\author{
Kossi Kini ${ }^{1,2} \cdot$ Rachelle Dossa $^{1} \cdot$ Bernadin Dossou ${ }^{1} \cdot$ Mariame Mariko $^{1} \cdot$ Ralf Koebnik $^{2} \cdot$ Drissa Silué $^{1,3}$ (ID
}

Received: 16 November 2018 / Accepted: 22 January 2019

(c) The Author(s) 2019

\begin{abstract}
The isolation, purification and accurate diagnosis of Pantoea and many other bacterial species that infect rice are essential for upstream studies. However, some isolates of Pantoea and other bacteria such as Sphingomonas have similar biochemical and morphological features on common culture media and are thus difficult to isolate selectively and accurately diagnose. We thus developed a semi-selective medium containing $65 \mathrm{~g} / 1(65 \%) \mathrm{NaCl}$ that allows growth of all Pantoea strains, but inhibits other microorganisms. It can be used to isolate and purify Pantoea spp. for preliminary diagnosis.
\end{abstract}

Keywords Pantoea genus $\cdot$ Rice pathogens $\cdot$ Africa $\cdot$ Semi-selective medium $\cdot$ Disease diagnosis

Numerous pathogens (e.g., nematodes, fungi, viruses and bacteria) cause diseases on rice in Africa and around the world (Séré et al. 2013). Bacteria causing diseases include Xanthomonas oryzae pv. oryzae and X. oryzae pv. oryzicola, Burkholderia spp., Pseudomonas spp., Sphingomonas spp., and Pantoea spp. (Cui et al. 2016; Duveiller et al. 1988; Kini et al. 2017a, b, c; Poulin et al. 2015; Wonni et al. 2011, 2014; Zhu et al. 2008). The three Pantoea species that were reported earlier as rice pathogens in other continents have only recently been described as such in Africa (Kini et al. $2017 \mathrm{~b}, \mathrm{c}$ ) and were isolated from rice seeds and leaves in several countries (Dossou and Silue 2018). On certain culture media, X. oryzae pathovars and species of Burkholderia, Pseudomonas, Sphingomonas and Pantoea have similar phenotypic characteristics (e.g., pigmentation, shape, colony elevation), so biochemical and molecular methods are

Electronic supplementary material The online version of this article (https://doi.org/10.1007/s10327-019-00862-w) contains supplementary material, which is available to authorized users.

Drissa Silué

D.Silue@ cgiar.org

1 AfricaRice, Plant Pathology, B.P. 2031, Cotonou, Benin

2 IRD, CIRAD, Université de Montpellier, IPME, Montpellier, France

3 Present Address: AfricaRice, Plant Pathology, M'bé Research Station, 01, B.P. 2551, Bouaké 01, Côte d'Ivoire needed to differentiate them. In addition, seeds and leaves can be co-infected by Pantoea spp. and Sphingomonas spp. (Afolabi et al. 2014; Dossou and Silue 2018). Consequently, it is difficult to obtain pure colonies of the bacteria from each genus, so that eliminating contamination and making accurate, reliable diagnosis are a challenge. Methods to obtain pure cultures and identify them are needed. Present semi-selective media for fungi and bacteria including Pantoea (Mamede et al. 2018) do not discriminate between the bacterial species mentioned above.

The genus Pantoea has 27 species, five of which cause damage to several crops (Arnold et al. 2003; Block et al. 1998; Coutinho and Venter 2009; Cruz et al. 2007; De Maayer et al. 2014). P. ananatis, P. agglomerans and P. stewartii are responsible for more than $80 \%$ of the reported cases of plant disease. Because Pantoea isolates are more or less halophilic and can establish in environments with varying concentrations of salt (Silini-Cherif et al. 2012; Silvi et al. 2013), this property can be used to develop culture media, such as PA 20 developed by Goszczynska et al. (2006) specific for $P$. ananatis. PA 20 contains $20 \% \mathrm{NaCl}$ (w/v), crystal violet, and thallium nitrate, with a $\mathrm{pH}$ of 8.0 and suppresses the growth of bacteria and fungi (Goszczynska et al. 2006; Norris et al. 1976). The aim of the present study was to develop an easily prepared, inexpensive medium that is specific for the growth and isolation of strains of the genus Pantoea using these halophilic properties. Such a medium would facilitate the diagnosis and isolation of Pantoea strains collected from different rice plant organs (leaves, stems and 
seeds) especially when these organs are apparently healthy (e.g., seed).

The new medium we developed contains 11 of sterile distilled water ( $\mathrm{pH} 7.1 \pm 0.2) ; 65 \mathrm{~g} \mathrm{NaCl} ; 0.001 \mathrm{~g}$ crystal violet; $8.5 \mathrm{~g}$ sodium thiosulfate; $13.5 \mathrm{~g}$ agar; $10 \mathrm{~g}$ peptone; and $10 \mathrm{~g}$ sucrose and prepared as follows:

1. Heat the mixture while stirring until all the constituents have dissolved.

2. Autoclave at $121{ }^{\circ} \mathrm{C}$ for $20 \mathrm{~min}$.

3. Allow medium to cool but not solidify. Then pour it into Petri dishes and allow medium to solidify in a laminar flow cabinet.

4. Place the Petri dishes of medium in a plastic bag, seal and store either in a laminar flow cabinet or refrigerator $\left( \pm 5^{\circ} \mathrm{C}\right)$ until used.

Peptone sucrose agar (PSA) comprises 11 distilled sterile water, $10 \mathrm{~g}$ peptone, $10 \mathrm{~g}$ sucrose, $16 \mathrm{~g}$ agar, and $1 \mathrm{~g}$ glutamic acid, $\mathrm{pH}$ adjusted to $7.1 \pm 0.2$ using $1 \mathrm{M} \mathrm{KOH}$ and $\mathrm{NaOH}$ buffers. Nutrient agar (NA) contains 11 distilled sterile water, $0.5 \%$ peptone, $0.3 \%$ beef extract yeast extract, $1.5 \%$ agar, $0.5 \% \mathrm{NaCl}$, and $28 \mathrm{~g}$ nutrient agar powder; $\mathrm{pH}$ adjusted to neutral (6.8) using $1 \mathrm{M} \mathrm{KOH}$ and $\mathrm{NaOH}$ buffers at $25{ }^{\circ} \mathrm{C}$. Each medium is heated while stirring to fully dissolve all ingredients, autoclaved at $121{ }^{\circ} \mathrm{C}$ for $20 \mathrm{~min}$, cooled but not solidified, then poured into Petri dishes.

The selective efficacy of the media was tested using 89 isolates of Pantoea species, 23 of P. agglomerans, 32 of $P$. ananatis, and 148 of $P$. stewartii (Table 2 in supplemental data file) from the culture collection of the Africa Rice Center (and thus labeled as ARC). They were isolated from rice seeds and leaves in paddy fields or from seed stored in Benin and Togo as described by Kini et al. (2017a, b). In addition, seven reference strains from the French Collection of Phytopathogenic Bacteria (or CFBP, Angers, France), and the following referenced isolates from the Africa Rice strain bank were also used: X. oryzae pv. oryzae (6), X. oryzae pv. oryzicola (6), Sphingomonas spp. (5), Baccilus spp. (9), Burkholderia spp. (2) and Pseudomonas spp. isolates (2). The characteristics of all the isolates used are given in Table 1 of the supplemental data file. Strains of Sphingomonas and Pantoea from the AfricaRice strain bank were diagnosed using, respectively, a monoplex and a Multiplex PCR scheme developed by Kini et al. (2017a, 2018).

Selectivity and specificity of the Pantoea genus-specific agar (PGSA), was tested by plating the pure isolates and reference isolates mentioned above on the PGSA and the non-selective PSA and NA. The experiments were repeated tree times.

Each rice grain was soaked for $5 \mathrm{~min}$ in a solution of sodium hypochlorite $(1 \% \mathrm{w} / \mathrm{v})$ and then ethanol $(70 \% \mathrm{v} / \mathrm{v})$ and later washed 3 times with distilled sterile water for surface sterilization. A metallic forceps, sterilized with alcohol then with a dry bead sterilizer at $250{ }^{\circ} \mathrm{C}$, was then used to place 25 sterilized seed in three circles around the surface of each plate of PGSA, PSA and NA. All seed plating was done in a laminar flow cabinet. Pieces of diseased rice leaves $\left(1 \mathrm{~mm}^{2}\right)$ were surface-sterilized as described for the seeds, crushed or macerated in distilled sterile water, and the resulting sap was placed on plates of the three media.

Growth of the different bacteria, fungi and other microorganisms on the different media was monitored daily. The phenotypic characteristics of the different colonies of bacteria were then recorded.

Tests with the 301 Pantoea strains, including the 13 reference strains (Tables 1 and 2 in the supplemental data file), and 27 isolates of $X$. oryzae pv. oryzae, X. oryzae pv. oryzicola, Sphingomonas spp., Bacillus spp., Burkholderia spp. and Pseudomonas spp., showed that (i) only Pantoea strains grew on PGSA (Fig. 1); (ii) bacteria of other genera did not grow on PGSA (Fig. 1); and (iii) no fungi grew on PGSA. Conversely, numerous bacterial and fungal colonies grew on PSA and NA (data not shown). After $48 \mathrm{~h}$, an average of 20 Pantoea colonies grew on PGSA and had the characteristics described below but had purple color borders (Fig. 1). After $72 \mathrm{~h}$ for PSA and NA and $96 \mathrm{~h}$ for PGSA, colonies of $P$. ananatis and $P$. agglomerans were pale yellow, floury and very viscous, and had coalesced. Those of $P$. agglomerans were not floury. For $P$. stewartii, the colonies had coalesced after $48 \mathrm{~h}$ on PSA and NA and $72 \mathrm{~h}$ on PGSA, but the colonies were not very viscous but sticky. They were light yellow, and the presence of water reduced the color intensity in certain places. On the other hand, an average of 40 beige to yellow colonies grew on PSA and NA, $24 \mathrm{~h}$ after plating. These colonies were round, convex and smooth with well-differentiated borders. Most of the other 92 unknown (Pantoea sp.) formed colonies on NA, PSA and PGSA in less than $24 \mathrm{~h}$ (data not shown).

Pantoea genus-specific agar (PGSA) enabled growth of all isolates belonging to the Pantoea genus but not other bacteria and fungi. In fact, the 301 diverse Pantoea isolates tested were able to grow on PGSA and on NA and PSA, but their growth and diagnosis on NA and PSA were compromised by the proliferation of fungi and other bacteria (see Tables 1 and 2 in supplemental data file). By contrast, isolates of $X$. oryzae pv. oryzae, X. oryzae pv. oryzicola, Sphingomonas, Baccilus, Burkholderia and Pseudomonas did not form colonies on PGSA but did so on NA and PSA. In addition, fungal colonies grew on PSA and NA but not on PGSA. PGSA is thus specific for the growth of isolates of the genus Pantoea. It contains sodium chloride $(65 \%$ $\mathrm{w} / \mathrm{v}$ ), sodium thiosulfate, and crystal violet and has a $\mathrm{pH}$ of $7.1 \pm 0.2$. The PA 20 medium of Goszczynska et al. (2006) also contains crystal violet and thallium nitrate but inhibits the growth of fungi and other bacteria only at $\mathrm{pH}$ 8.0. 


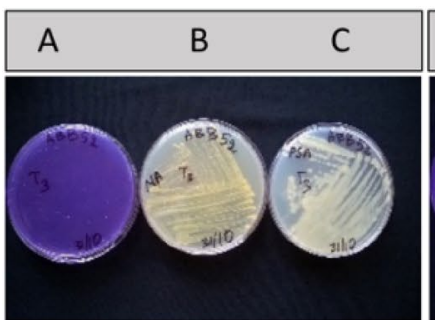

Xanthomonas oryzae pv. oryzae

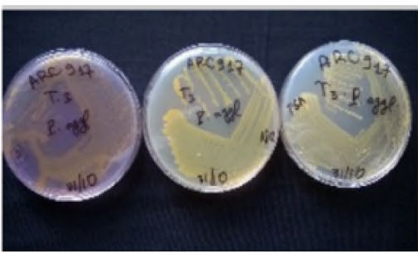

Pantoea agglomerans

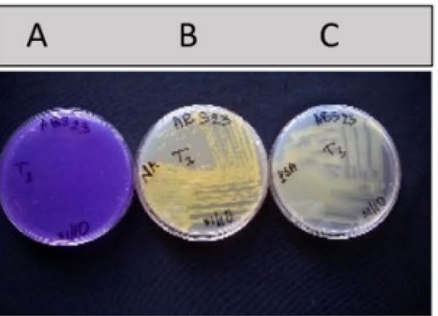

Xanthomonas oryzae pv. oryzicola

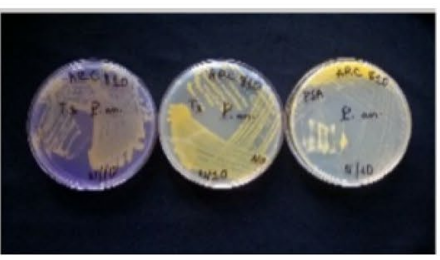

Pantoea ananatis

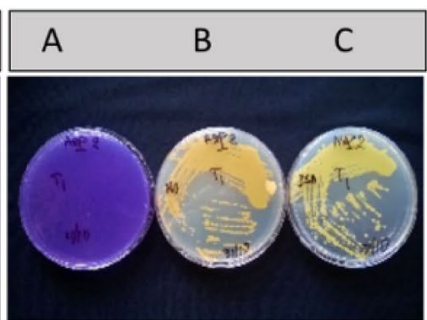

Sphingomonas spp.

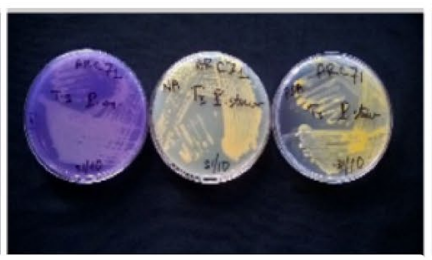

Pantoea stewartii

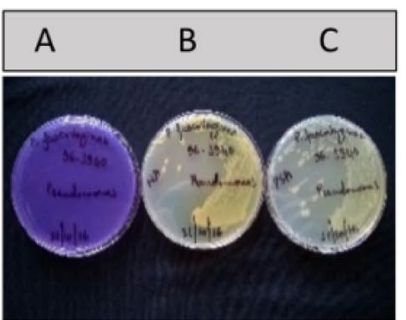

Pseudomonas fuscovaginae

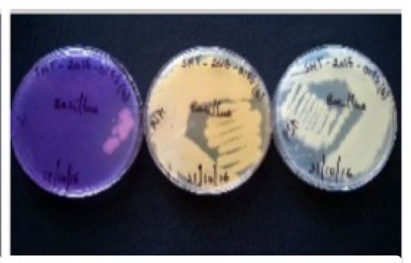

Bacillus spp.
Fig. 1 Bacterial colonies after 10-12 days growth on Pantoea-genusspecific agar (A), peptone sucrose agar (PSA) (B) and nutrient agar (NA) (C). Pantoea ananatis, P. stewartii and P. agglomerans grew

Therefore, the role of $\mathrm{pH}$ in the selective efficacy of the PGSA medium needs to be further investigated.

Crystal violet and $\mathrm{NaCl}(65 \%$ w/v) in PGSA probably contributed to the lack of growth of other bacteria and fungi as suggested by Goszczynska et al. (2006) and Norris et al. (1976). In fact, Goszczynska et al. (2006) mentioned that the combination of D-arabitol, $\mathrm{pH}, \mathrm{NaCl}$ concentration and thallium nitrate contributed to the selectivity of PA 20. In addition, the unwanted fungi and bacteria likely did not have the halophilic properties of Pantoea spp., which would explain their inhibition on PGSA. It is unclear, however, whether the halophilic properties of the Pantoea species are responsible for the successful isolation of Pantoea strains using PA 20 or PGSA. Further investigations are therefore needed.

Pantoea genus-specific agar will complement PA 20 for diagnosing Pantoea species and is not meant to be used alone. It can be used as a preliminary diagnostic tool that complements existing cultural, biochemical and molecular diagnostic methods (Kini et al. 2017a, b, 2018). It will facilitate the isolation of strains collected on seeds or from sap from crushed leaves.

In conclusion, the newly developed PGSA medium can be used to purify isolates contaminated by other bacteria such as Sphingomonas spp. It requires only a few affordable ingredients and can be easily prepared in less-equipped laboratories, including those of Plant Quarantine Services in Africa. It is will be particularly useful for preliminary diagnostic tests when Pantoea spp. are suspected, especially well on all media, whereas Xanthomonas, Sphingomonas, Bacillus, and Pseudomonas and fungi were inhibited by the selective medium but grew well on PSA and NA

on seeds. However, it cannot replace further testing of other characteristics, including pathogenicity of any isolates obtained. In fact, some of these Pantoea species might not be pathogenic to crops. Thus, the usual procedures for handling microbial cultures should be strictly respected.

Acknowledgements Dr. Kossi Kini benefited from a PhD scholarship from the French Research Institute for Sustainable Development (IRD) within the programme "Allocation de Recherche pour une Thèse au Sud" (ARTS), a grant from the International Foundation for Science (IFS), and financial support from the Ministry of Foreign Affairs (Japan) and the Global Rice Science Partnership (GRiSP) through AfricaRice. All these institutions are gratefully acknowledged. We thank Toyin Afolabi (AfricaRice, Cotonou, Benin), Sandrine Fabre and Florence Auguy (IRD, CIRAD, University of Montpellier, IPME, Montpellier, France) for excellent technical support.

\section{Compliance with ethical standards}

Conflict of interest The authors declare that they have no conflict of interest.

Human/animal rights This article does not contain any studies with human participants or animals performed by any of the authors.

Open Access This article is distributed under the terms of the Creative Commons Attribution 4.0 International License (http://creativeco mmons.org/licenses/by/4.0/), which permits unrestricted use, distribution, and reproduction in any medium, provided you give appropriate credit to the original author(s) and the source, provide a link to the Creative Commons license, and indicate if changes were made. 


\section{References}

Afolabi O, Milan B, Poulin L, Ongom J, Szurek B, Koebnik R et al (2014) First report of Xanthomonas oryzae pv. oryzicola causing bacterial leaf streak of rice in Uganda. Plant Dis 98:1579

Arnold DL, Pitman A, Jackson RW (2003) Pathogenicity and other genomic islands in plant pathogenic bacteria. Mol Plant Pathol $4: 407-420$

Block CC, Hill JH, McGee DC (1998) Seed transmission of Pantoea stewartii in field and sweet corn. Plant Dis 82:775-780

Coutinho TA, Venter SN (2009) Pantoea ananatis: an unconventional plant pathogen. Mol Plant Pathol 10:325-335

Cruz AT, Cazacu AC, Allen CH (2007) Pantoea agglomerans, a plant pathogen causing human disease. J Clin Microbiol 45:1989-1992

Cui Z, Ojaghian MR, Tao Z, Kakar KU, Zeng J, Zhao W, Duan Y, Vera Cruz CM, Li B, Zhu B, Xie G (2016) Multiplex PCR assay for simultaneous detection of six major bacterial pathogens of rice. J Appl Microbiol 120:1357-1367. https://doi.org/10.1111/ jam. 13094

De Maayer P, Yin Chan W, Rubagotti E, Venter SN, Toth IK, Birtch PRJ, Coutinho TA (2014) Analysis of the Pantoea ananatis pangenome reveals factors underlying its ability to colonize and interact with plant, insect and vertebrate hosts. BMC Genom 15:404. https://doi.org/10.1186/1471-2164-15-404

Dossou B, Silue D (2018) Rice pathogens intercepted on seeds originating from 11 African countries and from the USA. Seed Sci Technol 46:31-40

Duveiller E, Miyajima K, Snacken F, Autrique A, Maraite H (1988) Characterization of Pseudomonas fuscovaginae and differentiation from other fluorescent pseudomonads occurring on rice in Burundi. J Phytopathol 122:97-107. https://doi. org/10.1111/j.1439-0434.1988.tb00995.x

Goszczynska T, Venter SN, Coutinho TA (2006) PA 20, a semi-selective medium for isolation and enumeration of Pantoea ananatis. J Microbiol Methods 64:225-231

Kini K, Agnimonhan R, Afolabi O, Milan B, Soglonou B, Gbogbo V, Koebnik R, Silue D (2017a) First report of a new bacterial leaf blight of rice caused by Pantoea ananatis and Pantoea stewartii in Benin. Plant Dis 101:242-242. https://doi.org/10.1094/ PDIS-06-16-0940-PDN

Kini K, Agnimonhan R, Afolabi O, Soglonou B, Silue D, Koebnik R (2017b) First report of a new bacterial leaf blight of rice caused by Pantoea ananatis and Pantoea stewartii in Togo. Plant Dis 101:241. https://doi.org/10.1094/PDIS-06-16-0939-PDN

Kini K, Agnimonhan R, Dossa R, Soglonou B, Gbogbo V, Ouedraogo I, Kpemoua K, Traoré T, Silue D (2017c) First report of Sphingomonas sp. causing bacterial leaf blight of rice in Benin, Burkina Faso, The Gambia, Ivory Coast, Mali, Nigeria, Tanzania and Togo. New Dis Rep 35:32. https://doi.org/10.519 7/j.2044-0588.2017.035.032
Kini K, Agnimonhan R, Dossa R, Silué D, Koebnick R (2018) A diagnostic multiplex PCR scheme for identification of plantassociated bacteria of the genus Pantoea. bioRxiv https://doi. org/10.1101/456806

Mamede MC, Tebaldi ND, Mota LCBM, Martins OM, Coelho L (2018) Detection of Pantoea ananatis in corn seeds on semiselective medium. Trop Plant Pathol 43:254-256. https://doi. org/10.1007/s40858-017-0203-Z

Norris P, Man WK, Hughes MN, Kelly DP (1976) Toxicity and accumulation of thallium in bacteria and yeast. Arch Microbiol 110:279-286

Poulin L, Grygiel P, Magne M, Gagnevin L, Rodríguez-R L, Forero Serna N, Zhao S, El Rafii M, Dao S, Tekete C, Wonni I, Koita O, Pruvost O, Verdier V, Vernière C, Koebnik R (2015) New multilocus variable-number tandem-repeat analysis tool for surveillance and local epidemiology of bacterial leaf blight and bacterial leaf streak of rice caused by Xanthomonas oryzae. Appl Environ Microbiol 81:688-698. https://doi.org/10.1128/AEM.02768-14

Séré Y, Fargette D, Abo ME, Wydra K, Bimerew M, Onasanya A, Akator SK (2013) Managing the major diseases of rice in Africa. In: Wopereis MCS, Johnson DE, Ahmadi N, Tollens E, Jalloh A (eds) Realizing Africa's rice promise. CABI, Wallingford, pp 213-228

Silini-Cherif H, Silini A, Ghoul M, Yadav S (2012) Isolation and characterization of plant growth promoting traits of a rhizobacteria: Pantoea agglomerans 1ma2. Pak J Biol Sci 15:267-276

Silvi S, Barghini P, Aquilanti A, Juarez-Jimenez B, Fenice M (2013) Physiologic and metabolic characterization of a new marine isolate (BM39) of Pantoea sp. producing high levels of exopolysaccharide. Microbe Cell Fact 12:10

Wonni I, Ouedraogo L, Verdier V (2011) First report of bacterial leaf streak caused by Xanthomonas oryzae pv. oryzicola on rice in Burkina Faso. Plant Dis 95:72

Wonni I, Cottyn B, Detemmerman L, Dao S, Ouedraogo L, Sarra S, Tekete C, Poussier S, Corral R, Triplett L, Koita O, Koebnik R, Leach J, Szurek B, Maes M, Verdier V (2014) Analysis of Xanthomonas oryzae pv. oryzicola population in Mali and Burkina Faso reveals a high level of genetic and pathogenic diversity. Phytopathology 104:520-531

Zhu B, Lou M, Huai Y, Xie G, Luo J, Xu L (2008) Isolation and identification of Burkholderia glumae from symptomless rice seeds. Rice Sci 15:145-149. https://doi.org/10.1016/S1672 $-6308(08) 60033-5$

Publisher's Note Springer Nature remains neutral with regard to jurisdictional claims in published maps and institutional affiliations. 